\title{
The Determinants of Corporate Cash Holding in Indonesia: Manufacturing Company
}

\author{
Muhammad Ilham Prasetyo Sitorus \\ sitorusilham@gmail.com \\ Accounting Study Program, Faculty of Business \\ President University, Cikarang, Indonesia \\ Ika Pratiwi Simbolon \\ ika.pratiwi@president.ac.id \\ Accounting Study Program, Faculty of Business \\ President University, Cikarang, Indonesia \\ Andrianantenaina Hajanirina \\ hajanirina@president.ac.id \\ Accounting Study Program, Faculty of Business \\ President University, Cikarang, Indonesia
}

\begin{abstract}
This research has the purpose of analyzing the cash flow, capital expenditures, liquid assets, tangible assets, bank debt, firm size, research and development, growth opportunities, leverage, cash flow volatility, managerial ownership toward cash holding. The population in this research are all manufacturing firms listed on the Indonesia Stock Exchange (IDX). The sampling technique uses a purposive sampling method, and 78 observations have obtained from 26 companies for the 2016-2018 period. The method used in this research is quantitative. The results of this study indicate that liquid assets, tangible assets, and leverage have significant impact on cash holdings. In contrast, cash flow, bank debt, capital expenditure, firm size, research and development, growth opportunities, cash flow volatility, and managerial ownership do not have significant impact on cash holding.
\end{abstract}

Keywords: cash holding; leverage; liquid asset; tangible asset

\begin{abstract}
Abstrak
Penelitian ini bertujuan untuk menganalisa arus kas, belanja modal, asset likuid, aset berwujud, hutang bank, ukuran perusahan, penelitian dan pengembangan, peluang pertumbuhan, leverage, volatilitas arus kas, kepemilikan manajerial terhadap kepemilikan uang tunai. Populasi dalam penelitian ini adalah semua perusahaan manufaktur yang terdapat di Bursa Efek Indonesia (BEI). Teknik penentuan sampel menggunakan metode purposive sampling dan sampel diperoleh 78 observasi yang berasal dari 26 perusahaan untuk periode 2016-2018. Metode yang digunakan dalam penelitian ini adalah metode kuantitatif. Hasil penelitian ini menunjukkan bahwa asset likuid, aset berwujud, dan leverage memiliki dampak terhadap kepemilikan uang tunai sedangkan arus kas, belanja modal hutang bank, ukuran perusahan, penelitian dan pengembangan, peluang pertumbuhan volatilitas arus kas, dan kepemilikan manajerial tidak memiliki dampak terhadap kepemilikan uang tunai.
\end{abstract}

Kata kunci: kepemilikan uang tunai; solvabilitas; aset likuid; aset berwujud 


\section{INTRODUCTION}

In the corporate finance literature, corporate cash holding has been attracting a major of research in recent years and tends to continue protruding (Opler, et.al., 1999; Foley, et. al, 2007; Ferreria and Vilela, 2004). The researchers are interested in the importance of the cash amount on the company's balance sheet. A company uses cash holding to maintain daily working, to overdue debts, to fund growth through profitable investment projects, etc. Hence, if the firms are not able to produce adequate cash, a difficult time could expect unless some external preference money sources can be discovered. (Uyar \& Cemil, 2014). However, the judgment about how much cash could hold at least as necessary as garnering money from the customer or earning it from other sources. In terms of carrying much cash reserves than needed on hand or vice versa, the company spends several costs and gains few benefits. For instance, as a result of having unused cash excessively, a company could incur opportunity costs by forgoing profitable investments. Yet, it might be secure from financial trouble. Contrarily, keeping less money than needed might remove, causing opportunity costs, while at the same time creating a company becoming susceptible to financial difficulty (Uyar \& Cemil, 2014). Therefore, cash holding can be seen as something that can be converted into cash in accounting terms, better known as cash and equivalent cash. In 2018, Pyridam Farma Tbk., Siantar Top Tbk., Wismilak Inti Makmur Tbk., Semen Indonesia (Persero), Lion Metal Works Tbk., and HM Sampoerna Tbk., held cash from total assets with each percentage of $1.04 \%, 2.43 \%, 6.93 \%, 10.25 \%, 21.72 \%$, and $33.29 \%$. This data comes from the financial statements of firms in Indonesia. The cash percentage variation of the company's total assets shows that several factors affect the company's cash holding.

This research is examining the impact of managerial ownership, in which managerial ownership is a new variable on determinants of corporates cash holding. (Uyar \& Cemil, 2014) had examined the firm-specific especially in Turkish firms, they had viewed from various aspects that affect the cash holding choices such as cash flow, capital expenditures, liquid asset, bank debt, multinationality, asset tangibility, size, cost of research and development, investment/growth opportunities, cash flow volatility, and leverage. Yet, from their investigation or research, they have not learned more about the managerial ownership as for the aspect that may affect the cash holding. Based on that, the author wants to examine managerial ownership because, free cash flow theory has shown the managers have an incentive to hold a significant cash amount for its goals rather than shareholders' (Jensen, 1986). Thus, when managers have ownership, they purpose to maximize company value rather than using the company's resources for their benefits (Abdioğlu, 2016). It is following from prior research (Uyar \& Cemil, 2014) suggestion for future research to explore other factors on corporate cash holding that can be useful to be analyzed.

\section{LITERATURE REVIEW}

\section{Trade off theory}

Trade-off theory stated that the firm arranges its optimal cash holding extent by considering the trade-off between the marginal benefits and the costs are involved in holding such as a liquid asset (Al-Najjar \& Belghitar, 2011). The corporate cash holding determinants have been a subject of explanation in trade-off theory (Oppler, 1999; Wasiuzzaman, 2014; Nguyen, et. al, 2016). The primary benefit of holding cash is forming safety protection, which enables the company to avoid the external fundraising costs or liquidating existing assets and allows the company to fund its growth opportunity. (Ferreira \& Vilela, 2004), showed three benefits in holding cash for the company. First, cash could decrease the chance of financial distress and could serve as an alternative to handle the unexpected losses and 
limitations on fundraising. The second cash holding is helping to fulfill the company's investment plans, considering the restrictions to raise funds, and therefore permitting the company to invest their positive Net Present Value (NPV) projects. Third, holding cash can decrease fundraising costs and liquidation costs, if needed.

\section{Pecking order theory}

According to (Myers \& Majluf, 1984), pecking order theory showed an explanation for corporate financing behavior so that companies tend to emphasize internal funding sources rather than external funding. This theory indicates that the companies do not have the target cash level, yet cash uses as a buffer between retained earnings and investment needs. Eventually, when retained earnings are not adequate to fund new investments, firms will use cash holdings, after that issuing new debt. When firms can pay off debt, they will be issuing securities (Kariuki, et al., 2015).

\section{Cash flow and Cash Holding}

A report presenting information about cash inflows or outflows of a firm at a specified period is the definition of cash flow. According to (Kim et al., 2011), the result of their study showed the cash flow from operation decrease the need to hold cash reserves means that cash flow and cash holding have a negative relation. The result of (Opler et al., 1999) showed the research subject that generates cash flow is prefer to hold some cash for the purpose of financing investment and will use it until the right time comes because to run the company is not always that smooth or when they are facing the difficult time. Based on that statement, indicates that cash holding and cash flow have positive relations. It corresponds with pecking order theory, which stated that a firm with high cash flow tends to hold cash significantly. Also, there are supporting arguments from prior research (Ozkan \& Ozkan, 2004) and (Uyar \& Cemil, 2014).

\section{$H_{1}:$ Cash Flow has positive impact on Cash Holding}

\section{Capital Expenditures and Cash Holding}

Kim, et al., 2011 stated that capital expenditures improve new assets, and these assets facilitate loans as collateral. Thereby bigger loans eventually the necessity of cash holding. Besides, the pecking order theory stated cash balance is the result of investment decisions. Therefore, the increasing amount of capital expenditure will decrease the holding of cash and vice versa, and this means that between cash holding and capital expenditure are correlated but shows the negative relation (Bates et al., 2009).

\section{$\mathrm{H}_{2}$ : Capital Expenditure has negative impact on Cash Holding}

\section{Liquid Assets and Cash Holding}

At a time of cash shortfall, liquid assets might be liquidated to fulfill cash necessity and becoming cash substitutes (Ferreira \& Vilela, 2004). The advantage of holding non-cash liquid is quickly turning it into cash as compare to other assets. Maintaining an adequate liquid assets amount can decrease the chance of applying to the capital market to increase funds (Ozkan \& Ozkan, 2004).

\section{$H_{3}$ : Liquid Asset has negative impact on Cash Holding}

\section{Asset Tangibility and Cash Holding}

Assets divided into intangible and tangible, the more amount of tangible assets rather than the intangible is expected to hold less liquid assets because when the company is facing 
the shortfall, they can use the physical assets for cash or as the guarantee while issuing debt. It had proven that asset tangibility has a negative impact on cash holding based on (Drobetz \& Grüninger, 2007).

\section{$\mathrm{H}_{4}$ : Asset Tangibility has negative impact on Cash Holding}

\section{Bank Debt and Cash Holding}

Bank debt is one of the cash alternatives, and it is essential in establishing the cash holding amount (Bigelli et al., 2012). A company that has more bank debt in capital structure will face supervision from financial institutions that reduce the managerial discretion of decisions about cash holding (Basheer, 2014). The argumentation of the trade-off model based on the premise that once a company establishes banks as a significant source of financing, those banks will get in-depth knowledge not only about the financials but also about strategic planning.

\section{$H_{5}$ : Bank debt has negative impact on Cash Holding}

\section{Size and Cash Holding}

Trade-off theory stated that firms' size has a reverse relation with cash holding since big firm tends to invest in different growth opportunities rather than reserve them. The result of research conducted by (Ferreira \& Vilela, 2004) showed between firm size, and cash holdings have negative relationship.

\section{$H_{6}:$ Size has negative impact on Cash Holding}

\section{Costs R\&D and Cash Holding}

A company that has high $R \& D$ costs expect to hold much cash because a company will have a high level of risk when facing the high expenditure of $R \& D$, that caused them to keep much money for defending themselves against potential losses (Chen, 2008). The R\&D expenditure variable might use to measure two things - growth opportunities or financial distress cost (D’Mello et al., 2008). Opler, et al., 1999 stated that the most important presence of the $R \& D$ costs is the information that must be asymmetric. While information asymmetry is essential, cash flow shortfall will result in decreasing the company's investment, leading to higher costs of financial trouble. According to the trade-off theory, this argument supports the statement of costs R\&D and cash holding have a positive relation on its level (Bates et al., 2009).

\section{$H_{7}:$ Costs $R \& D$ has positive impact on Cash Holding}

\section{Growth/Investment Opportunities and Cash Holding}

Pecking order theory reveals that firms with more growth options usually have an informational disadvantage, which results in more expensive external financing. Between growth opportunity and cash holdings could demonstrate thorough research conducted by (Opler et al., 1999) showed a company with significant growth opportunity holds large amounts of cash means that both of the variables have positive relation.

\section{$H_{8}:$ Growth/Investment Opportunities has positive impact on Cash Holding}

\section{Leverage and Cash Holding}

Firms with a low level of leverage make a lack of oversight from external parties so that it allows for greater managerial discretion when cash is at a higher level manager can use 
it to benefit themselves (Ferreira \& Vilela, 2004). According to the trade-off theory (Ozkan \& Ozkan, 2004) an empirical investigation of UK firms stated that between leverage and cash holding have a negative relation, firms with higher debt ratios have lower cash positions.

\section{$H_{9}:$ Leverage has negative impact on Cash Holding}

\section{Cash Flow Volatility and Cash Holding}

A firm with an unstable cash flow has the opportunity to spend cash at one time. Several costs can cause firms to lack cash, for example, such as bankruptcy costs. To protect against this, it would be better if the company saves more cash. Based on this explanation, according to the trade-off theory, between the volatility of cash flow and cash holdings are estimated a positive relationship. (Rahmawati \& Zahrotun, 2013).

\section{$H_{10}:$ Cash flow volatility has positive impact on Cash Holding}

\section{Managerial Ownership and Cash Holding}

Managerial ownership in an equal company will cause a stable cash holding level in a firm. If the managers have high managerial ownership, they can maintain their position and tend to perform opportunistic behavior such as using the company's cash assets excessively, thereby reducing the level of cash holding. This condition can disrupt the company's operational activities and make the company becomes unstable (Mawardi \& Nurhalis, 2018).

\section{$H_{11}$ : Managerial Ownership has negative impact on Cash Holding}

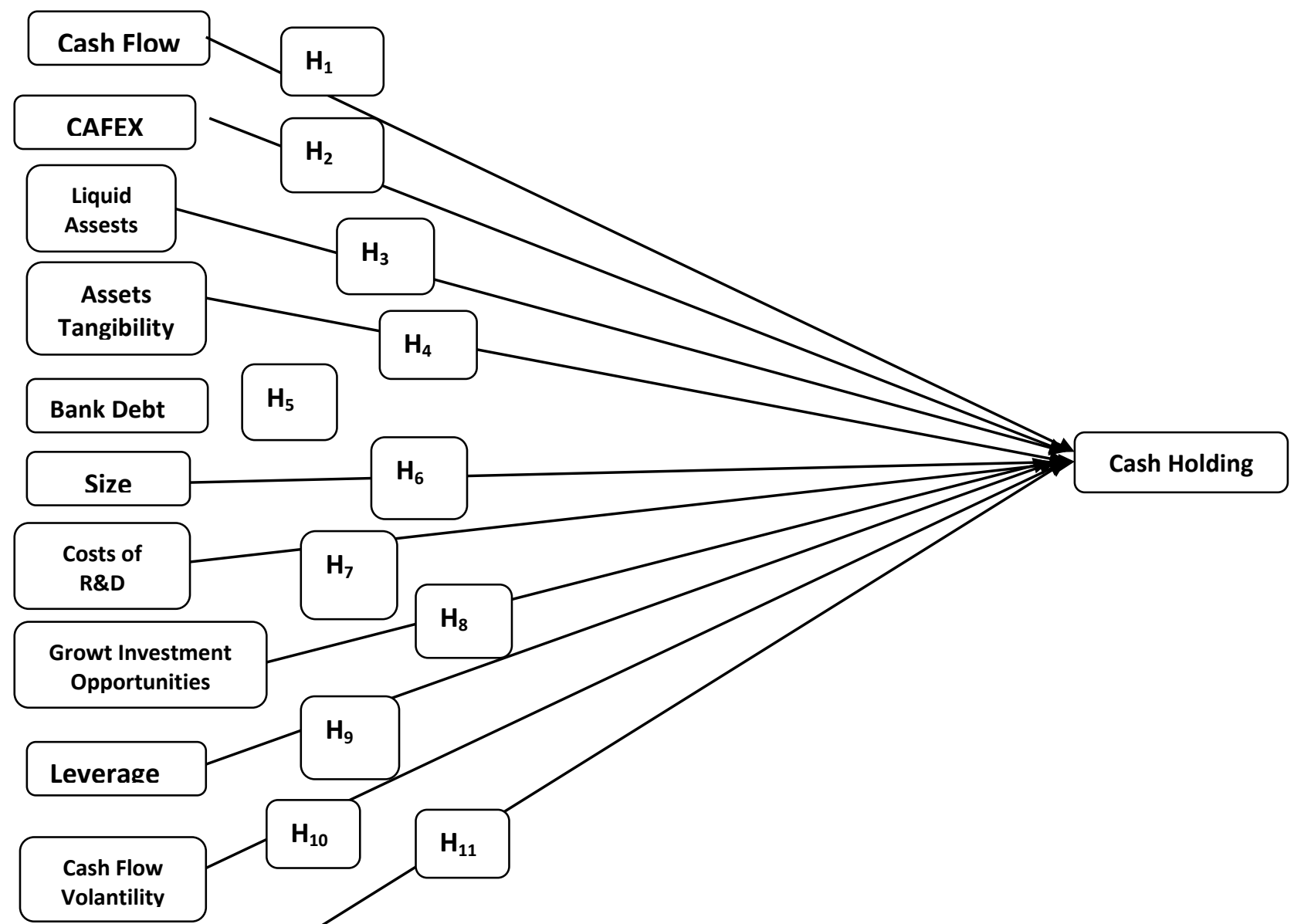

Figure 1. Research Framework 


\section{RESEARCH METHOD}

The purpose of this research is to reveal the relationships between variables by using multiple-regression analysis. The researcher attempted to explain the effect of cash flow, capital expenditures, liquid assets, asset tangibility, bank debt, firm size, R\&D costs, growth opportunities, leverage, cash flow volatility, managerial ownership, to the dependent variable, cash holding of 26 firms listed on Indonesia Stock Exchange (IDX) starting from 2016 until 2018. Based on the hypotheses, the explanation of the variable and its measurement, the researcher creates the model as follows:

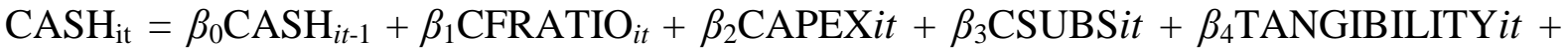 $B_{5}$ FINDEBT $i t+\beta_{6}$ FSIZE $i t+\beta_{7}$ RD $i t+\beta_{8}$ MTOB $i t+\beta_{9}$ LEVERAGE $i t+$ $\beta_{10}$ VOLATILITYit $+\beta_{11}$ MOit $+\alpha_{t}+u_{i t}$

Where:

$\begin{array}{ll}\text { CASH } & =\text { Cash holdings } \\ \text { CFRATIO } & =\text { Cash Flow } \\ \text { CAPEX } & =\text { Capital Expenditures } \\ \text { CSUBS } & =\text { Non-cash as substitutes } \\ \text { TANGIBILITY } & =\text { Tangible asset } \\ \text { FINDEBT } & =\text { Financial Debt } \\ \text { SIZE } & =\text { The natural log of total assets } \\ \text { RD } & =\text { Research and Development } \\ \text { MTOB } & =\text { Market to book ratio } \\ \text { LEV } & =\text { Leverage } \\ \text { VOLATILITY } & =\text { Cash flow volatility } \\ \text { MO } & =\text { Managerial Ownership }\end{array}$

\section{RESULT AND DISCUSSION}

\section{Hypothesis Testing Result}

Table 1. Partial Test

\begin{tabular}{ccccc}
\hline Dependent Variable: SQR(CH) & & & & \\
\hline Variable & Coefficient & Std. Error & t-Statistic & Prob. \\
C & 0.009548 & 0.481144 & 0.019845 & 0.9842 \\
CFRATIO & -0.096319 & 0.094133 & -1.023218 & 0.3099 \\
CAPEX & 0.056121 & 0.076961 & 0.729206 & 0.4685 \\
CSUBS & -0.440041 & 0.114490 & -3.843482 & 0.0003 \\
TANGIBILITY & -0.276241 & 0.111547 & -2.476453 & 0.0158 \\
FINDEBT & $-4.93 E-15$ & $3.86 \mathrm{E}-15$ & -1.278886 & 0.2054 \\
FSIZE & 0.021074 & 0.016183 & 1.302220 & 0.1974 \\
RD & -0.017260 & 0.471168 & -0.036632 & 0.9709 \\
MTOB & 0.003598 & 0.005344 & 0.673304 & 0.5031 \\
LEV & -0.344025 & 0.104000 & -3.307935 & 0.0015 \\
VOLATILITY & 0.083629 & 0.065833 & 1.270318 & 0.2084 \\
MO & 0.016075 & 0.117775 & 0.136489 & 0.8918 \\
\hline
\end{tabular}

Source: Data from Eviews 9, Processed on 2019 
If p-value is less than 0.05, the hypothesis is accepted (Holmes, Illowsky and Dean, 2018). According to Table, the result above stated that the probability of CSUBS, TANGIBILITY, and LEV are 0.0003, 0.0158, and 0.0015 which less than 0.05 . It indicates that profitability of CSUBS, TANGIBILITY, and LEV can have an impact on Cash Holding. Meanwhile, the probability of CFRATIO, CAPEX, FINDEBT, FSIZE, RD, MTOB, VOLATILITY, and MO are 0.3099, 0.4685, 0.2054, 0.1974, 0.9709, 0.5031, 0.2084 and 0.8918 respectively which greater than 0.05 . It indicates that CFRATIO, CAPEX, FINDEBT, FSIZE, RD, MTOB, VOLATILITY, and MO do not have an impact on Cash Holding. This result has supported $\mathrm{H}_{3}, \mathrm{H}_{4}, \mathrm{H}_{9}$ but not supported $\mathrm{H}_{1}, \mathrm{H}_{2}, \mathrm{H}_{5}, \mathrm{H}_{6}, \mathrm{H}_{7}, \mathrm{H}_{8}, \mathrm{H}_{10}$, and $\mathrm{H}_{11}$

\section{Cash Flow to Cash Holding}

Correspond to the trade-off theory, cash flow is assumed to become liquidity sources and could be substituted for cash. Thus, a company with a large cash flow tends to hold less cash. When a firm has less cash flow to operate the business, they will use cash holding as a source of funds to substitute cash flow. However, this result is not significant because firms in Indonesia do not concern about cash flow. It happens because the condition of firms in Indonesia usually has subsidiaries to provide facilities for external funding (Jinkar, 2013).

\section{Capital Expenditures to Cash Holding}

The result aligned by the research of (Amalia et al., 2018), which stated that high/low capital expenditure is not affected cash holding. The condition could occur when a company invested in fixed assets or does not engage in capital expenditures. Thus it will not affect the cash holding amount. Trade-off theory stated that the firm that has higher capital expenditures would be holding cash as protection against transaction costs associated with external capital and opportunity costs on inadequate resources and cash holding increase to finance the company's capital expenditure. Still, the need for cash holdings will decrease when the company has cash replacements such as debt.

\section{Liquid Assets as a Cash Substitute to Cash Holding}

When a firm uses a higher level of liquid assets, the less cash the company holds. According to the trade-off theory, when a company's net- working capital is bigger, firms shall keep less because it can be substituted. This result aligned with prior research (Uyar \& Cemil, 2014). If a company in an urgent situation, cash will be needed either for paying short-term liabilities or making payment for operating expenses since altering liquid assets is easier and cheaper than other assets (Uyar \& Cemil, 2014).

\section{Asset Tangibility to Cash Holding}

When the firms need cash urgently, they can sell asset tangibility. Based on (Drobetz \& Grüninger, 2007), physical assets could be sold if a cash deficiency happens and that company with more assurance encounters fewer problems issuing debt. This result is aligned with prior research (Uyar \& Cemil, 2014), which stated that asset tangibility has negative relation and a significant effect on cash holding.

\section{Bank Debt to Cash Holding}

The result is aligned by the study of (Ferreira \& Vilela, 2004), which stated that a company that uses more bank debt holds less cash. It happens because when the firm still needs a source of funds from external funding, which is debt, the firm tends to not using the cash holding, which is they have a source of funds from a bank. But, in this research the result is not significant because there are things that need to be considered by firms in Indonesia, if the firm is independent and it is difficult to obtain external funding, the firm 
must pay attention to internal funding sources so that company liquidity is maintained (Jinkar, 2013). Moreover, it is supported by the view that bank is in a better place to assess the credit quality of the company, to monitoring, and controlling the company's financial policy, reducing problems of asymmetry and agency that are usually associated with other types of debt.

\section{Size to Cash Holding}

If seen from the trade-off theory, large companies with all their abilities have access to enter the capital market, so that large companies are easier to get facilities from external parties. It is what makes many large companies reduce the amount of money held or no cash reserves at all. Besides, the larger size of the company, the greater the obligations that must be met by the company. Instead, it does not apply to small firms that usually have limitations to access the capital market so that smaller firms have more cash held to meet their operational needs. This result is aligned with a prior study of (Bates et al., 2009), (Ferreira \& Vilela, 2004).

\section{Costs of R\&D to Cash Holding}

Based on (Opler et al., 1999) in their research argue that firms will have less accumulated cash because of an investment in R\&D. The statement of (Opler et al., 1999) is supported by the pecking order theory. Whereas corporate financing behavior so that companies tend to prioritize internal funding sources rather than external funding (Myers \& Majluf, 1984). When R\&D cost is increasing, then cash holding will be decreasing because the company uses its cash to invest in R\&D activities. The result of the study shows there are negative relation and no significant association between $R \& D$ and cash holding. This result is aligned by the study of (Uyar \& Cemil, 2014) under the test used GMM regression for predicting the cash holding.

\section{Growth/Investment Opportunities to Cash Holding}

Regarding the result had done by the statistical analysis above, the result is aligned with (Bigelli et al.,2012), which showed growth opportunity does not affect the company's cash holding. Companies that have substantial growth opportunities prefer to get external funding rather than internal funding in the form of cash holding (Gill \& Shah, 2012). It was also uttered by (Bigelli et al.,2012) that companies that have a high growth opportunity tend to choose a short-term loan for their fund instead of using their cash holding.

\section{Leverage to Cash Holding}

The firms with high leverage have low cash holding, which is corresponding to the pecking order. Pecking order theory argued that a high level of debt, as well as small cash holding, occur at the same time when firms' investment exceeds retained earnings. (Ferreira \& Vilela, 2004) argued that companies with low leverage make a lack of supervision from external parties. Therefore, it allows for greater managerial discretion when cash is at a higher level so that managers can use it to benefit themselves. Another underlying reason is that high leverage reflects the ease of a firm to get external funding. It is a basis because a company with significant leverage does not hold much cash because they consider providing lower returns when compared to investments in other assets. Thus, a company with a high leverage level will have a little cash holding level. It has supported by research conducted by (Bates et al., 2009) (Ferreira \& Vilela, 2004), between leverage and cash holding have negative relation. 


\section{Cash Flow Volatility to Cash Holding}

Following the study of (Islam, 2012), their result stated that there was an insignificant relation between CF Volatility toward Cash Holding. The result shows, there is a diversity of volatility in each company. In this study, some companies have sharp volatility, while other companies have less sharp cash flow volatility. That causes the variable CF Volatility does not impact the Cash Holding. The positive relationship in this research is aligned with the Trade-off theory, whereas by avoiding liquidity crises, a company with high cash flow variation holds much cash. The firm which can prevent the unexpected cost of liquidity and increase the chances of survival are firms with volatile cash flow. The positive relation is aligned by the study of (Ferreira \& Vilela, 2004) (Bigelli et al.,2012) (Ozkan \& Ozkan, 2004). Therefore, the result shows between CF Volatility with Cash Holding have a positive relation yet not significant.

\section{Managerial Ownership to Cash Holding}

Following agency theory, with managerial ownership in the company, agency problems that occur between management, owners and shareholders can be reduced. But the proportion of share ownership should not be too large because it can pose a danger to the company. With large managerial ownership, the manager has voting rights and a strong position to control the company, and it also creates difficulties for external shareholders to manage the manager's actions (Mawardi \& Nurhalis, 2018). The positive relation aligned by study of (Lee \& Lee, 2009). The outcome of this study is aligned by the study of (Mawardi \& Nurhalis, 2018), which stated that managerial ownership had negative effect on cash holding.

\section{CONCLUSION}

After analyzing and getting the results from all the steps. Cash flow has a negative and insignificant impact on cash holding. Capital expenditures have a positive and insignificant impact on cash. Liquid assets have a negative yet significant impact on cash holding. Asset tangibility has a negative yet significant impact on cash holding. Bank debt has a negative and insignificant impact on cash holding. Size has a positive and insignificant impact on cash holding. Leverage has a negative as well as a significant impact on cash holding. Growth/Investment opportunity has a negative and insignificant impact on cash holding. Costs of R\&D has a negative as well as insignificant impact on cash holding. Volatility of cash flow has a positive and insignificant impact on cash holding. Managerial ownership has a positive as well as insignificant impact on cash holding.

This research only focuses on the manufacturing sector. Therefore, it is recommended to do further research on another segment of the business. The period used by the author of this study is a quite short length of time, only covers 3 years, and the sample only 26 firms. For future research in which will have quite similar topics and models, they could investigate other factors that will affect cash holdings, such as profitability and dividend payment. Also, the types of industries such as agriculture, mining, and real estate.

\section{REFERENCES}

Abdioğlu, N. (2016). Managerial ownership and corporate cash holdings: Insights from an emerging market. Business and Economics Research Journal, 7(2), 20-41.

Akinyom, O. J. (2014). Effect of cash management on profitability of Nigerian manufacturing firms. International Journal of Marketing and Technology, 4(1), 129140. 
Al-Najjar, B., \& Belghitar, Y. (2011). Corporate cash holdings and dividend payments: evidence from simultaneous analysis. Managerial and Decision Economics, 32(4), 231-241.

Amalia, C. I., Arfan, M., \& Saputra, M. (2018). The Effect of financial leverage and capital. International Journal Of Academic Research In Business \& Social Sciences, 8(5), 311-318.

Baker, H., Kent, \& Gerald, S. M. (2011). Capital structure and corporate financing decision: Theory, evidence and practice. USA: John Wiley \& Sons Ltd.

Basheer, M. F. (2014). Impact of corporate governance on corporate cash holdings: An empirical study of firms in manufacturing industry of Pakistan. International Journal of Innovation and Applied Studies, 7(4), 1371-1383.

Bates, T. W., Kathleen, M. K., \& Rene, M. S. (2009). Why do US firms hold so much more cash than they used to? The Journal of Finance, 64(5), 1985-2021.

Bigelli, M., Sánchez, \& Vidal, J. (2012). Cash Holdings in private firms. Journal of Banking \&Finance, 36(1), 26-35.

Chen, Y. R. (2008). Corporate governance and cash holdings: Listed New economy versus old economy firms. Corporate Governance: An International Review, 16(5), 430-442.

D’Mello, R., Krishnaswami, S., \& Larkin, P. J. (2008). Determinants of corporate cash holdings: Evidence from spin-offs. Journal of Banking and Finance, 38(1), 12091220.

Drobetz, W., \& Grüninger, M. C. (2007). Corporate cash holdings: Evidence from Switzerland. Financial Markets and Portfolio Management, 21(3), 293-324.

Ferreira , A., \& Vilela, S. (2004). Why do firms hold cash? Evidence from EMU countries. European Financial Management, 10(2), 295-319.

Foley, C. F., Hartzell, J. C., Titman, S., \&Twite, G. (2007). Why do firms hold so much cash? A tax-based explanation. Journal of Financial Economics, 86(3), 579-607.

Gill, A., \& Shah, C. (2012). Determinants of corporate cash holdings: Evidence from Canada. International Journal of Economics and Finance, 4(1), 70-79.

Holmes, A., Illowsky, B.s and Dean, S. (2018). Introductory business statistics. Rice University.

Ijeoma, N. B. (2016). Relationship between earnings and cash flow in estimating cash flows: Evidence from listed. Journal of Research in Business, Economics and Management,, 6(1), 804-814.

Islam, S. (2012). Manufacturing firms' cash holding determinants: Evidence from. International Journal of Business and Management, 7(6). 172-184

Jensen, M. (1986). Agency costs of free cash flow, corporate finance and takeovers. American Economic Review, 76(2), 323-329.

Jinkar, R. T. (2013). Analisa faktor-faktor penentu kebijakan cash holding. Mini Economica, 42, 129-146.

Kariuki, Samuel, N., Gregory, S., Namusonge, \& George, O. (2015). Determinants of corporate cash holdings: Evidence from private manufacturing firms in Kenya. International Journal of Advanced Research in Management and Social Sciences, 4(6), 15-33.

Kim, J., Kim, H., \& Woods, D. (2011). Determinants of corporate cash-holding levels: An Empirical Examination of the restaurant industry. International Journal of Hospitality Management, 30(3), 568-574.

Lee, K. W., \& Lee, C. F. (2009). Cash Holdings, corporate governance structure. Review of Pacific Basin Financial Markets and Policies, 12(3), 475-508.

Masood, A., \& Shah, A. (2014). Corporate governnace and cash holding in listed nonfinancial firms in Pakistan. Business Review, 9(2), 48-73. 
Mawardi, \& Nurhalis. (2018). Pengaruh corporate governance terhadap cash holding pada perusahaan manufaktur di Bursa Efek Indonesia. Jurnal Managemen dan Inovasi, 9(1), 75-90.

Myers, S. C., \& Majluf, N. S. (1984). Corporate Financing and investment decisions when firms have information that investors do not have. Journal of Financial Economics, $13(2), 187-221$.

Nguyen, T., L. H., Nguyen, L. N. T., and Le, T. P. V. (2016). Firm value, corporate cash holdings and financial constraint: A study from a developing market. Australian Economic Papers, 55: 368-85.

Opler, T., Pinkowitz, L., Stulz, R., \& Williamson, R. (1999). The determinants and implications of corporate cash holdings. Journal of Financial Economics, 52(1), 3-46.

Ozkan, A., \& Ozkan, N. (2004). Corporate cash holdings: An empirical investigation of UK Companies. Journal of Banking \& Finance, 28(9), 2103-2134.

Pinkowitz, L., \& Williamson, R. (2001). Bank power snd cash holdings: Evidence from Japan. Review of Financial Studies, 14(4), 1059-1082.

Rahmawati, \& Zahrotun, A. (2013). Faktor-faktor yang mempengaruhi keputusan cash holding pada perusahaan food and beverages yang terdaftar di Bursa. Jurnal Ilmiah Mahasiswa FEB Universitas Brawijaya, 2(2), 1-15.

Uyar, A., \& Cemil, K. (2014). Determinants of corporate cash holdings: Evidence from the Emerging market of Turkey. Applied Economics, 46(9), 1035-1048.

Wahidahwati, W. (2002). Pengaruh Kepemilikan manajerial dan kepemilikan institusional pada kebijakan hutang perusahaan: Sebuah perspektif theory agency. The Indomesian Journal of Accounting Research, 5 (1) 1-16.

Wasiuzzaman, S. (2014), Analysis of corporate cash holdings of firms in Malaysia. Journal of Asia Business Studies, 8(2), 118-135. 